\title{
The Utilization of Transformation of Normalized Difference Vegetation Index (NDVI) for Healthy Forest Assessment
}

\author{
$1^{\text {st }}$ Dian Ayu Larasati \\ Department of Geography, Faculty of \\ Social Sciences and Law \\ Universitas Negeri Surabaya \\ Surabaya, Indonesia \\ dianlarasati@unesa.ac.id
}

\author{
$2^{\text {nd }}$ Heru Setiawan \\ Makassar Research and Development \\ Centre for Environment and Forestry \\ Environment and Forestry Research \\ and Development Institute of Makasar \\ Makasar, Indonesia \\ hiero_81@yahoo.com
}

\author{
$3^{\text {rd }}$ Muzayanah \\ Department of Geography, Faculty of \\ Social Sciences and Law \\ Universitas Negeri Surabaya \\ Surabaya, Indonesia \\ muzayanah@unesa.ac.id
}

\begin{abstract}
Nanggala III Natural Park is a nature conservation area which has a very important role in sustaining the life of the community. Assessment of forest health in the region is essential as a tool to evaluate to evaluate this area in order to provide sustainable benefits. This study aims to assess the level of health forest in Nanggala III Natural Park using Normalized Difference Vegetation Index (NDVI) and remote sensing. This study uses transformation of vegetation index and field observation, while the sampling method used purposive sampling method. Indicators for assessing forest health level using analysis of vegetation index (NDVI) using Landsat 8, recorded in 2015. Zoning to determine the level of forest health based on the pixel values of image transformation vegetation index. Based on the results of data processing, it can be seen that in general, the forest area in Nanggala III Natural Park categorized in the healthy forest. Land cover is dominated by vegetation with high-density level with an area reaching 798.84 ha $(82.48 \%)$, then the vegetation densities in the medium with an area of 97.74 ha $(10.09 \%)$, sparse vegetation densities in the area 26.28 ha $(2.71 \%)$ and non-vegetation cover (cloud and build area) amounted to 45.72 ha $(4.72 \%)$.
\end{abstract}

Keywords-Vegetation density, NDVI, Remote sensing, Nanggala III Natural Park, South Sulawesi

\section{BACKGROUND}

This Forests are a natural resource that has an important role as the capital of Indonesia's development. Under Government Regulation No. 41 of 1999 [1], the forest ecosystem is defined as a form of landscape with biological natural resources dominated by trees in their natural environment; one and the other cannot be separated. Forests have a very important role in sustaining human life, both in terms of ecology and economy. In terms of ecology, the forest's function as a regulator of the water system, protection against floods and landslides, erosion control, genetic resources and role in absorbing greenhouse gases in the atmosphere. Functions of forests from an economic point of which is as a source of raw material industry, providing building material needs, sources of medicine, food resources, educational facilities and other human economic life support.

One forest in South Sulawesi containing a great contribution to society is Nanggala III Nature Park (NNP).
Nanggala III Nature Park is located in Palopo Regency, South Sulawesi Province. Based on The Government Regulation No. 28 of 2011 on the management of nature reserves and nature conservation area [2], Nature Park is defined as a Nature Conservation Areas (NCA) which is used mainly for the nature tourism and recreation. While NAC is a region with a certain characteristic, both land and water that have the principal function of the protection of life support systems, preserve the diversity of plants and animals, as well as the sustainable use of natural resources and ecosystems.

Nanggala III Nature Park has a main function for nature tourism and recreation. Besides functioned as nature tourism and recreation, this area is used as a water catchment area and springs protection areas. That is because in this area there are several springs that have large amount discharged and able to supply the water needs of the surrounding community. Water resources generated from the two main rivers located in Nanggala III Nature Park, namely Paredean River and Bambalu River. These rivers have a big role as water supplies for surrounding communities. Local Government (Palopo Regency) also use water resources from NNP to meet the water needs of their peoples managed by the Regional Water Company (PDAM) Palopo Regency. Besides being used as raw water the water flowing from the Bambalu River also used for the hydroelectric power plant.

The rapid population growth coupled with the everexpanding area woke will affect large enough to changes in the environmental order in the form of environmental degradation, environmental degradation/damage to the environment and natural resource depletion and land use change, including forest area in the NNP. Along with the communication development and transportation, as well as the increasing number of people living around the area, then many emerging areas woke up as the right of residence or place of business. This causes increased pressure on the area. Some of the more intense as a result of public pressure on the incidence of encroachment area are used for agricultural 89 ha, housing 153 families, lodging 2 units and theft of forest products/ illegal logging [3]. This condition if left unchecked it will continue to occur can degrade the quality of forests in providing the needs of the community. To prevent further 
damage, monitoring the health of forests needs to be done continuously. One form of monitoring of forest areas is using remote sensing technology.

The development of remote sensing technology provides the possibility to obtain data that is relatively new, fast, and accurate. Satellite remote sensing plays an important role in monitoring patterns of vegetation productivity across large areas of land [4] [5] [6]. The launch of satellites by the developed countries more and spur the development of remote sensing as a tool to obtain data on a reliable inventory of natural resources. Some of the reasons for the use of remote sensing methods for monitoring natural resources which are the result of sensing can be used to map a vast area with a fast, cost less, can map a variety of thematic maps at once and make the process faster. Landsat satellites, SPOT, ERS-1, NOAA, and others orbiting the earth with various types of sensors, spectral resolution, and spatial resolution is very beneficial users of satellite data in accordance with their needs. The number of channels on the Landsat Thematic Mapper that operate on channels that are sensitive to the spectral response of vegetation is very beneficial in the study or the study of vegetation. With the help of mathematical transformations in the form of vegetation index, the value of spectral vegetation can be highlighted, while the spectral value beyond the vegetation can be removed or eliminated, making it possible to do a study of the density of vegetation, Leaf Area Index (LAI), biomass, stand age, chlorophyll concentrations, and also nitrogen content [7]. This paper was aimed to assess the forest health at NNP using NDVI and remote sensing.

\section{RESEARCH METHODS}

\section{A. Time and Location}

The research activities carried out in the Nanggala III Natural Park. Bas on The Minister of Forestry Decree No. 663/Kpt-II / 1992 dated July 1, 1992, Nanggala III Natural Park has an area of 968.5 ha. Administratively, PPA located at Batang Barat Village, Wara Barat Sub-District, Palopo Regency. Geographically, the location of research is located between $120^{\circ} 04$ '01.05 "E - $120^{\circ} 05^{\prime}$ 56.17" E and $02^{\circ} 55$ '51.5 "LS - $2^{\circ} 58^{\prime}$ 55.42" LS. This research was conducted in 2015 .

\section{B. Materials and Tools}

Materials used in this research activity include forest areas of PPA were used as research objects. Tools used include the hardware tools which consist of a. a set of computer, GPS, digital cameras, and some types of software which are Global Mapper and ArcGIS.

\section{Type of data}

In this research, there are two types of data collected are primary data and secondary data. Primary data is data obtained by performing measurements and observations in the field. Some of the primary data taken in this study include data from interviews, photos, and results of direct observation in the field. Secondary data is the data derived from the literature that comes from reports and other sources related to the research topic. Some secondary data that will be taken include village monographs, statistical data related to the location and reports from agencies/institutions related to the study. Landsat 8 of 2015 downloaded from http://earthexplorer.usgs.gov/, a map of location research, and other thematic maps.

\section{D.Data Processing Method}

The method used in this research is NDVI Landsat 8 OLI 2015. As published by the USGS Landsat 8 satellite flying at an altitude of $705 \mathrm{~km}$ from the earth's surface and have a scan area measuring $170 \mathrm{~km} \times 183 \mathrm{~km}$ (similar to Landsat previous version), Landsat 8 satellite has sensors Onboard Operational Land Imager (OLI) and the Thermal Infrared Sensor (TIRS) with the number of channels as many as 11 band. Among these channels, 9 channels (band 1 -9) are in the OLI and the other 2 (bands 10 and 11) on TIRS. Most channels have specifications similar to Landsat 7. The production of vegetation density classes with NDVI method includes the following processes: (a). Geometric Correction, (b). Cutting the image (cropping) n; (c). Transformation NDVI calculated with the following formula:

$$
\text { NDVI }=\frac{\text { Near infrared band }- \text { Infrared band }}{\text { near infrared band }+ \text { Infrared band }}
$$

Results of NDVI extraction is information of vegetation index on each pixel with a value of -1 to 1 . A value close to -1 indicates the area has very sparse vegetation until no vegetation, and conversely, the value close to 1 indicates the area has dense vegetation. This value cannot be lowered to the percentage of vegetation cover but can be derived by comparing the percentage of vegetation cover in the field. Reclassification of vegetation density used Spatial Analyst by Arc GIS 1.0. NDVI class value then reclassified into three classes, dense, moderate and sparse.

\section{RESULTS AND DISCUSSION}

\section{A. Biophysical Conditions}

Forest type at Nanggala III Natural Park can be classified in the wet tropical rainforest that is experiencing rain throughout the year. Characteristics of tropical rainforests are characterized by green forest vegetation throughout the year. This area serves as a water catchment area that is useful in maintaining the stability of the soil water reserves. Area elevation data obtained from SRTM data (Shuttle Radar Topography Mission) are downloaded directly from the USGS. Excess SRTM image is, in addition, to easy to get, also has a high resolution to review the scale. The resolution provided for the study site for download is $30 \mathrm{~m}$, so as to obtain the use of SRTM elevation and slope data is done with a high enough level of accuracy. Based on SRTM data, it can be seen that the area of NNP is located at an altitude of 419 until 1,494 m above sea level.

The topography of the NNP region can be seen by looking at the appearance of the contour lines. Contour lines are imaginary line connecting points that have the same height of a datum/reference plane certain. Meeting contour lines symbolize field conditions with a steep slope, while the wide spaced contour lines symbolize the sloping topography. Making the contour lines is done by using SRTM data were processed using the software. Based on 
topographic maps, NNP region dominated by mountainous areas with the slope level is moderate to steep.

The slope of NNP areas is very varied, from flat to steep, but most are included in the very steep category. Based on the results of SRTM data analysis using the ArcGIS and Global Mapper software can know the composition of the slope in the NNP. Based on the analysis, it can be seen that the slope of NNP areas is dominated by a very steep grade with (a slope of more than 45\%) with the percentage of area reached $69.39 \%$, followed a steep grade (slope $25 \% \mathrm{~s} / \mathrm{d}$ $45 \%$ ) with the percentage of area reached $23.66 \%$, then the class rather steep (slope of $15 \% \mathrm{~s} / \mathrm{d} 25 \%$ ) with a percentage of $5.24 \%$ area, the next class of ramps (slope $8 \%$ s / d 15\%) with the percentage of area reached $1.62 \%$ and flat grade (slope $0 \mathrm{~s} / \mathrm{d} 8 \%$ ) and the percentage of area reached $0.09 \%$.

\section{B. Forest Cover}

Forest cover in NNP region is still pretty good because it is still dominated by trees of the jungle with a large diameter and height. Some compilers of forest vegetation in NNP include Agathis (Agathis dammara), Pine (Pinus mercusii), Uru (Elmerrillia ovalis), Cempaka (Michelia champaca), Pantobaka (Litsea sp.), Palm (Arenga pinnata), Dao (Dracontomelon dao), Suren (Toona sureni), Cemara Gunung (Casuarina junghuniana), Randu or kapok (Ceiba pentandra). In addition to woody vegetation, the vegetation there are also fruits like Durian (Durio zibethinus), Mangosteen (Garcinia sp), Sukun (Arthocarpus sp), Jambu (Syzygium sp) and Landsat (Lansium domesticum). Some types of woody plants do not include Pakis (Pityrogramma sp.) and Paku (Nephrolipis sp.).

The condition of forest cover in the NNP is still quite good, with a balanced composition of canopy strata between the upper layer, middle and bottom layer. The percentage of canopy closure at the observation plots an average of $50 \%$ to $80 \%$. The existence of standing trees with a balanced composition of the canopy strata was instrumental in keeping the regional hydrological cycle. The function of the canopy and undergrowth is intercepted (hold) of rain falling to the ground. Interception of rainwater is essential to reduce the power of rainwater at the soil surface, increasing the amount of rainwater into the ground slowly, and maintain microclimate. Thin water layer (Waterfilm) that remains on the surface of leaves and stems will then evaporate (evaporation). This case is important to maintain humidity.

The density of trees in an area can be used as an indicator of the health of the biophysical environment in the region. Regions with a high density of trees can create a microclimate that is different from a region with low tree density. According Hidayat [8] states that the density of trees significantly influences the number of bird species in an area. Observation of the density of trees is done by creating a sample plot area of $400 \mathrm{~m} 2$, then calculated the number of trees found in the area. The results of measurements in the field mentioned that NNP region has varying levels of density of trees. At the high-level tree, density consists of 175 to 250 trees/ha. At the level of medium density consisting of 125 to 150 trees/ha and the sparse level of 50 to 75 trees/ha.

\section{Transformation NDVI}

The levels of vegetation cover in NNP can be approximated by using index values of NDVI (Normalized Difference Vegetation Indices) were taken from Landsat 8. Transformation NDVI is one technique that has been used extensively for a variety of remote sensing applications [9]. NDVI is a simple index of vegetation is but has the highest sensitivity to changes in vegetation canopy density compared to another vegetation index [10]. NDVI is simply an index of 'greenness' of vegetation or vegetation photosynthetic activity, and one of the vegetation indexes most commonly used.

Vegetation index (NDVI) is based on the observation of different surface reflection of the earth. Active perform photosynthesis vegetation will absorb most of the red wave sunlight and reflect near-infrared waves higher. NDVI algorithms derived from the ratio between the bands of red and near-infrared bands of remote sensing image, so index of "greenness" of vegetation can be determined. Normalized Difference Vegetation Index (NDVI) is an index of the ratio most commonly used for vegetation. NDVI is calculated on a per-pixel normalization of the difference between the red and near-infrared band in the image. NIR is the value of near-infrared band to a cell and RED is the red band value for that cell. NDVI can be calculated for each image has a red and near-infrared bands. Biophysical interpretation of NDVI is the absorbed fraction of the photosynthetic active radiation.

Results of the NDVI extraction is vegetation index information on each pixel with a value of -1 to 1 . A value close to -1 indicates the area has very sparse vegetation until no vegetation, and conversely, the value close to 1 indicates the area has very dense vegetation. Many factors affect the intensity of the activity NDVI as photosynthesis in plants, the amount of vegetation cover, biomass, vegetation and soil moisture, and plants that stress (less healthy) and land cover. Statistical analysis of data NDVI in the Nanggala III Natural Park presented in Table 1.

Table 1. Statistic Data of NDVI Vegetation Index at Nanggala III Natural Park

\begin{tabular}{|l|l|l|}
\hline No & \multicolumn{1}{|c|}{ Parameters } & $\begin{array}{c}\text { Data Index } \\
\text { Vegetation NDVI }\end{array}$ \\
\hline 1. & Amount of Pixel & 10.762 \\
\hline 2. & Minimum pixel value & 0,0769 \\
\hline 3. & Maximum pixel value & 0,5450 \\
\hline 4. & Average pixel value & 0,4254 \\
\hline 5. & Standard deviation value & 0,0666 \\
\hline
\end{tabular}

Table 1 shows the vegetation index NDVI data statistics. NDVI vegetation index values were highest 0.5450 and the lowest 0.0769 with an average of 0.4254 . Average vegetation index close to 1 indicates that Nanggala III Natural Park region is dominated by areas with dense vegetation. To determine the spatial distribution of vegetation density at NNP then performed classifying vegetation index values. Based on the classification of NDVI values, obtained the distribution of land cover and stand density as shown in Figure 1. 


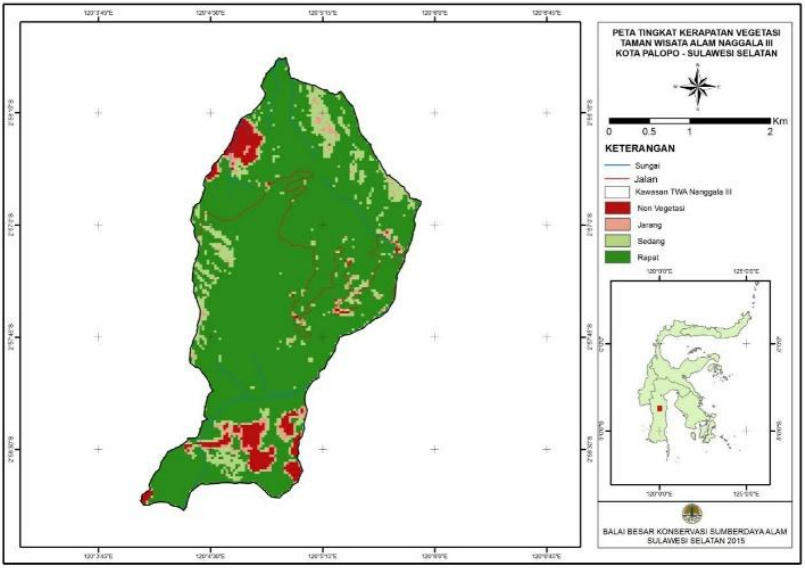

Figure 1. The vegetation density distribution map at Nanggala III Natural Park Palopo Regency, South Sulawesi Province

Based on Figure 1 can be seen that the result of NDVI classification indices produces land cover vegetation and non-vegetation (cloud, awakened area). The percentage of each level vegetation density can be seen in Table 2 .

Table 2. The vegetation density of Nanggala III Natural Park

\begin{tabular}{|l|l|l|l|l|}
\hline No & \multicolumn{1}{|c|}{ Parameters } & \multicolumn{1}{|c|}{$\begin{array}{c}\text { Amount } \\
\text { Pixel }\end{array}$} & \multicolumn{1}{|c|}{$\begin{array}{c}\text { Wide } \\
(\mathbf{H a})\end{array}$} & $\begin{array}{c}\text { Percentage } \\
(\boldsymbol{\%})\end{array}$ \\
\hline 1. & Non Vegetation & 508 & 45,72 & 4,72 \\
\hline 2. & Sparse vegetation & 292 & 26,28 & 2,71 \\
\hline 3. & $\begin{array}{l}\text { Medium vegetation } \\
\text { density }\end{array}$ & 1.086 & 97,74 & 10,09 \\
\hline 4. & $\begin{array}{l}\text { High density } \\
\text { vegetation }\end{array}$ & 8.876 & 798,84 & 82,48 \\
\hline
\end{tabular}

Based on the data presented in Table 2, it can be seen that the overall forest cover at Nanggala III Natural Park dominated by vegetation with high density level with an area reaching 798.84 ha $(82.48 \%)$, then the vegetation densities in the medium with an area of 97.74 ha $(10.09 \%)$, sparse vegetation densities in the area 26.28 ha $(2.71 \%)$ and nonvegetation cover (cloud and woke area) amounted to 45.72 ha $(4.72 \%)$.

\section{CONCLUSION}

Based on the of data processing results, it can be concluded that in general, the forest condition in the region Nanggala III Natural Park categorized in the good category. Land cover is dominated by vegetation with high-density level with an area reaching 798.84 ha $(82.48 \%)$, then the vegetation densities in the medium with an area of 97.74 ha $(10.09 \%)$, sparse vegetation densities in the area 26.28 ha $(2.71 \%)$ and non-vegetation cover (cloud and woke area) amounted to 45.72 ha $(4.72 \%)$.

\section{ACKNOWLEDGMENT}

The author would like to thank the Faculty of Social Sciences and Law, Universitas Negeri Surabaya and my colleagues who have served resources for this article.

\section{REFERENCES} Forestry." President, "The Government Regulation No. 28 of 2011 on the management of nature reserves and nature conservation area." BBKSDASS, Valuasi Ekonomi Air TWA Nanggala III Kota Palopo Provinsi Sulawesi Selatan. Makasar: Balai Besar Konservasi Sumberdaya Alam Sulawesi Selatan, 2014.

R. . Zhou, L., Tucker, C.J., Kaufmann, R.K., Slayback, D., Shabanov, N.V. And Myneni, "Variations in northern vegetation activity inferred from satellite data of vegetation index during 1981 to 1999," J. Geophys. Res., vol. 106, pp. 20069-20083, 2001.

C. . Shabanov, N.V., Zhou, L., Knyazikhin, Y., Myneni, R.B. And Tucker, "Analysis of interannual changes in northern vegetation activity observed in AVHRR data from 1981 to 1994," IEEE Trans. Geosci. Remote Sens., no. 40, pp. 115-130, 2002.

R. Stow, D.A., Hope, A.S., Mcguire, A.D., Verbyla, D., Gamon, J., Huermmrich, F., Houston, S., Racine, C., Sturm, M., Tape, K., Hinzman, L., Yoshikawa, K., Tweedie, C., Noyle, B., Silapaswan, C., Douglas, D.C., Griffith, B., Jia, G., Epstein, H., Walker, D., "Remote sensing of vegetation and land-cover change in Arctic tundra ecosystems," Remote Sens. Environ., vol. 89, pp. 281-308, 2004.

[7] Projo Danoedoro, Pengolahan Citra Digital: Teori dan Aplikasinya dalam Penginderaan Jauh. Yogyakarta: Fakultas Geografi. Universitas Gadjahmada, 1996.

[8] R. Hidayat, "Pengaruh kerapatan vegetasi dan kondisi lingkungan fisik terhadap jumlah jenis burung di Wanagama I, Gunung Kidul, Daerah Istimewa Yogyakarta," J. Prakt. Ris., pp. 1-7, 2014.

[9] S. Liang, Quantitative Remote Sensing of Land Surface. New Jersey: John Wiley \& Sons, Inc, 2004

[10] M. Mirza, "Hubungan Kerapatan Vegetasi dan NDVI Dalam Kaitannya dengan Estimasi Nilai Koefisien Aliran," Gadjah Mada University, 2005. 